\title{
Jurassic syn-rift sedimentation on a seawards-tilted fault block, Traill $\varnothing$, North-East Greenland
}

\author{
Henrik Vosgerau, Peter Alsen, lan D. Carr, Jens Therkelsen, Lars Stemmerik and Finn Surlyk
}

\begin{abstract}
Middle-Late Jurassic rifting in East Greenland was marked by westwards tilting of wide fault blocks bounded by major N-S-trending east-dipping synthetic faults. The syn-rift successions thicken westwards towards the faults and shallow marine sandstones show mainly southwards axial transport directions. An exception to this general pattern is found in south-east Traill $\varnothing$, which constitutes the E-tilted Bjørnedal Block, which is bounded to the west by the westwardsdipping antithetic Vælddal Fault. The stratigraphic development of the Jurassic succession on this block shows important differences to the adjacent areas reflecting a different tectonic development. Shallow marine sand seems initially to have filled accommodation space of the immediately adjacent block to the west. This block subsequently acted as a bypass area and much of the sediment was spilled eastwards onto the hangingwall of the east-dipping Bjørnedal Block. The succession on the Bjørnedal Block shows an eastwards proximal-distal decrease in sandstonemudstone ratio, reflecting increasing water depth and progressive under-filling of the subbasin towards the east in agreement with the dip direction of the fault block. The transverse, mainly south-eastwards palaeocurrents, the eastwards increase in water depths and decrease in sandstone-mudstone ratio on the Bjørnedal Block are at variance with the standard picture of westtilted blocks with southwards-directed palaeocurrents and decrease in grain size. Earlier palaeogeographic reconstructions have to be modified to account for the east-dipping hangingwall and different stratigraphic development of the area. The sea was thus open towards the east and there is no direct indication of a barrier or shoal east of Traill $\varnothing$.
\end{abstract}

Keywords: Bjørnedal Block, Jurassic, North-East Greenland, palaeocurrents, rifting, Traill $\varnothing$

\author{
H.V.*, J.T.* \& L.S., Geological Survey of Denmark and Greenland, Øster Voldgade 10, DK-1350 Copenhagen K, \\ Denmark. \\ Present addresses: *Roskilde Amt, Køgevej 80, DK-4000 Roskilde, Denmark. \\ ¡Skude E Jacobsen, Noestvedvej 1, DK-4760 Vordingborg. \\ P.A. \& F.S., Geological Institute, University of Copenhagen, Øster Voldgade 10, DK-1350 Copenhagen K, \\ Denmark. E-mail: petera@geol.ku.dk \\ I.D.C., Oxford Brookes University, Headington, Oxford OX3 OBP, UK.
}

The main Mesozoic rift phase in East Greenland was initiated in mid-Bajocian time, intensified during Bathonian-Oxfordian time, and culminated in the Kimmeridgian-Volgian. Rifting was accommodated along major north-south-trending and east-dipping normal faults limiting wide westwards-tilted blocks. This resulted in the development of elongated fault-controlled marine embayments open to the south and with major rivers entering the northern heads of the embayments located in relay zones where the border faults shifted en échelon to the east (Surlyk 1977a, 1978, 2003; Surlyk \& Clemmensen 1983). Transport of sand, silt and clay by marine currents was mainly axial towards the south. Initial Late Bajocian progradation of shallow marine sands reached the southern end of the exposed basin. The sandy system (Pelion Formation) 

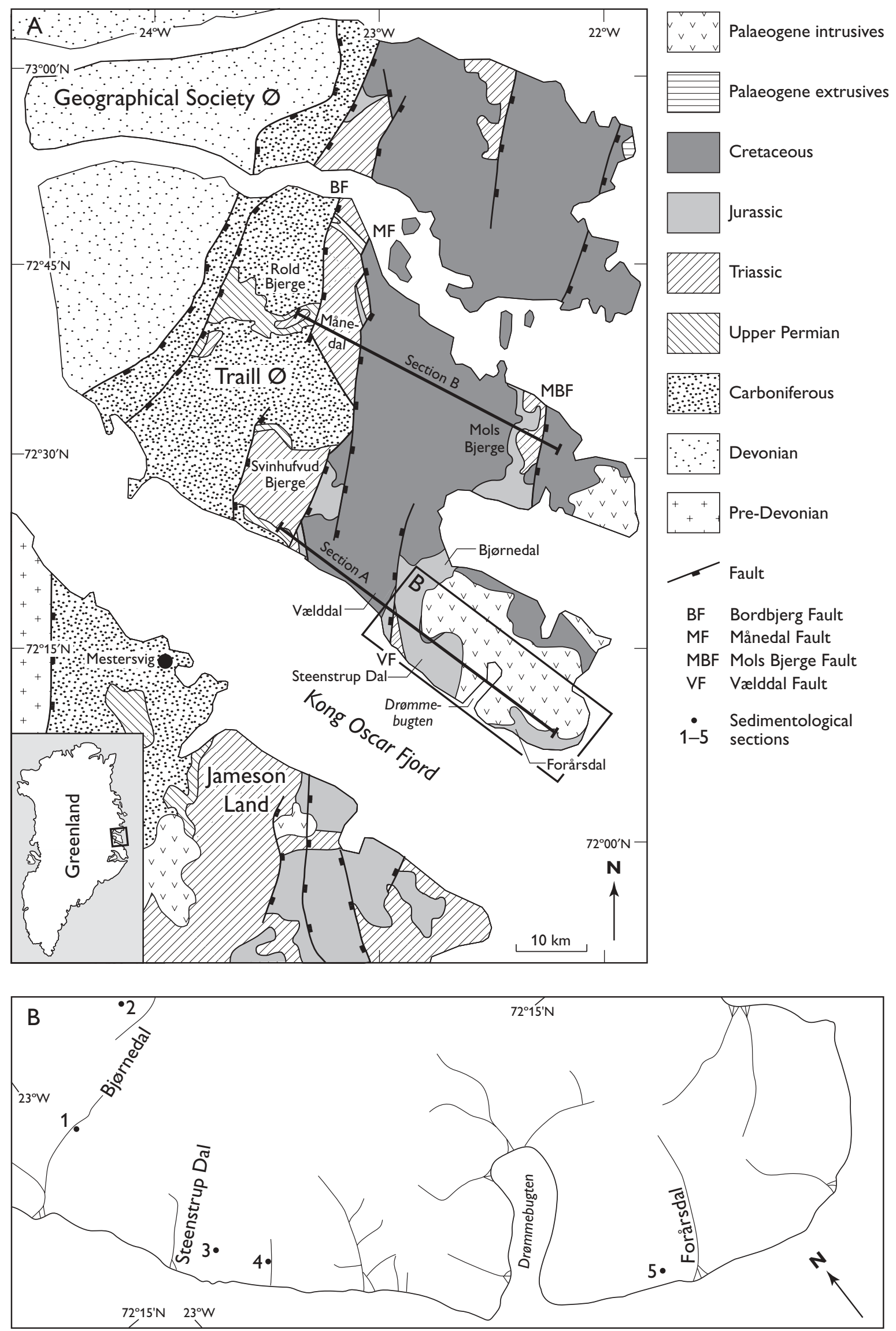


\section{South coast, Traill $\varnothing$ (Section A)}
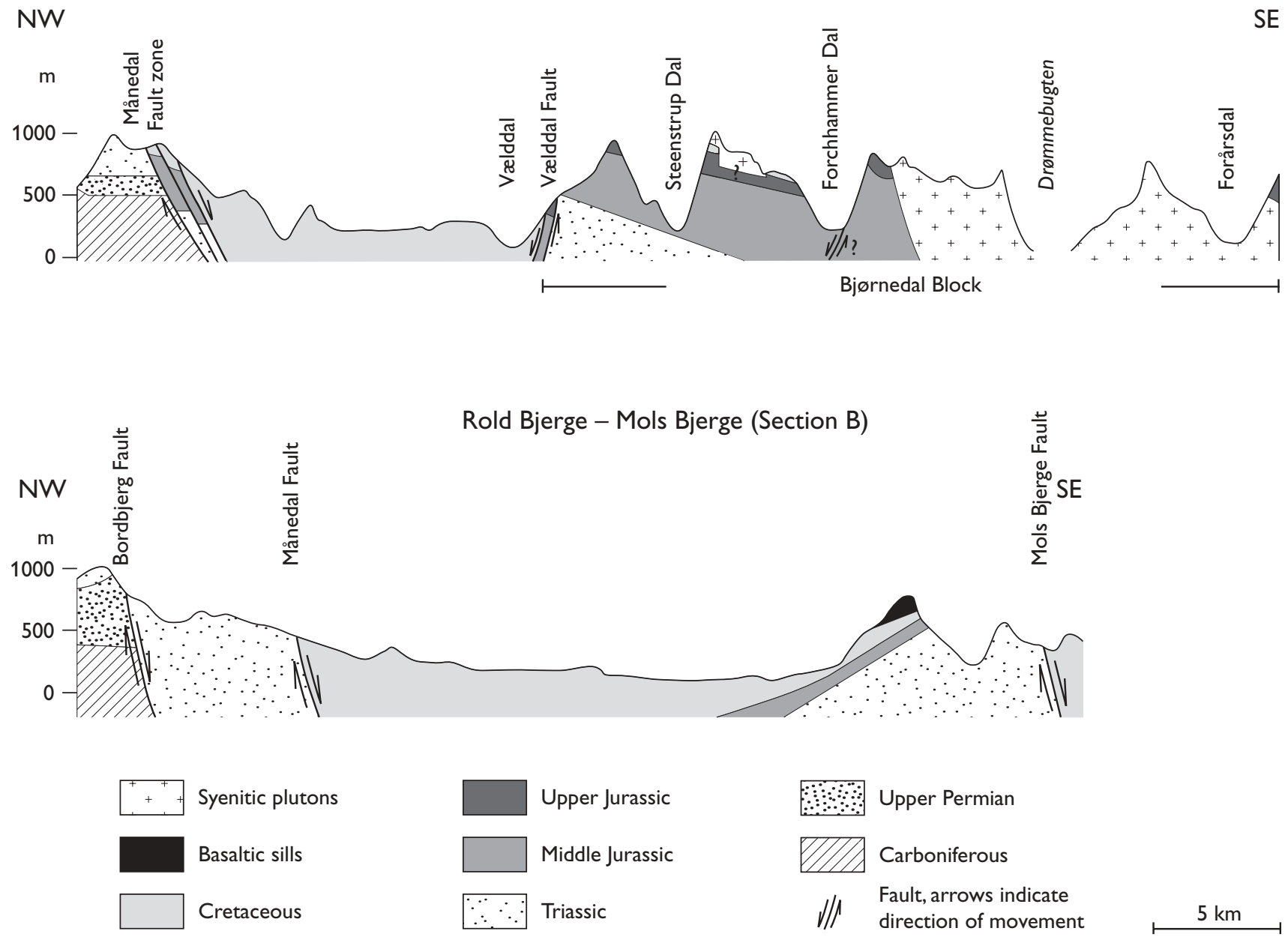

Fig. 2. NW-SE-oriented cross-sections showing the geological structure of eastern Traill $\varnothing$. Note the west-dipping Væelddal Fault, which forms the western limit of the Bjørnedal Block. Virtually all other Mesozoic faults in East Greenland dip towards the east and delimit westwards-tilted blocks. The positions of the sections are indicated on Fig. 1. Based on Koch \& Haller (1971).

progressively backstepped during the Bathonian and was eventually drowned in the Late Callovian due to increased rates of extension and a long-term eustatic rise in sea level (Engkilde \& Surlyk 2003; Surlyk 2003).

An exception to this simple pattern is found in southeastern Traill $\varnothing$, where an east-dipping fault block, more than $30 \mathrm{~km}$ wide, was formed during early rifting (Figs 1, 2; Carr 1998). It was limited to the west by the west-dipping Vælddal Fault (Donovan 1953; Carr 1998). The block, which is here termed the Bjørnedal Block, probably continues southwards into northern Jameson Land where poorly exposed east-dipping correlative strata occur on the south side of Kong Oscar Fjord (Fig. 1).

The aim of this study is to compare and contrast the syn-rift Middle-Late Jurassic stratigraphic syn-rift development on the eastwards-dipping Bjørnedal Block on south-east Traill $\varnothing$ with the rest of the Jurassic basin of East Greenland, which is characterised by westwards-tilted blocks.

\section{Facing page:}

Fig. 1. Map of Traill $\varnothing$ area showing the main faults and outcrops of the Jurassic succession. Positions of the structural cross sections (A, B) on Fig. 2 are indicated. Inset map (B) shows location of measured sedimentological sections (1-5). 


\section{The south coast of Traill $\varnothing$}

Upper Palaeozoic - Triassic deposits are exposed along the western part of the south coast of Traill $\varnothing$, whereas Jurassic and younger sediments are restricted to the eastern part (Fig. 1). The Jurassic succession is bounded to the west by the Månedal Fault and is cut by the Vælddal Fault situated $15 \mathrm{~km}$ further to the east (Figs 1, 2). The peninsula east of the Væelddal Fault is made up mainly by the Palaeogene Kap Simpson syenite complex which extends for about $30 \mathrm{~km}$ in a NW-SE direction parallel to the coast (Fig. 1). The coastal cliffs are high and steep, and numerous Palaeogene sills and dykes intrude the Jurassic succession. It has accordingly received very little attention. It was assigned to the Yellow and Black Series by Donovan (1953) and this was followed in the geological map of Koch \& Haller (1971). The Yellow Series was very loosely defined and covered Middle and lower Upper Jurassic sandstone-dominated successions. On Traill $\varnothing$, it includes the Pelion and Olympen Formations of current usage. The Black Series includes Upper Jurassic dark grey mudstones and black shales corresponding in part to the Bernbjerg Formation (Surlyk 1977b). Successively younger Jurassic strata are exposed from west to east along the coast east of the Væelddal Fault (Fig. 2). The succession includes Lower Bajocian sandstones and mudstones of the Bristol Elv Formation, Upper Bajocian - Lower Callovian sandstones of the Pelion Formation, Callovian mudstones of the Fossilbjerget Formation, intercalated with sandstones of the Parnas Member (top member of the Pelion Formation), overlain by Lower-Middle Oxfordian mudstones and sandstones of the Olympen Formation, and Upper Oxfordian Kimmeridgian dark grey and black mudstones of the Bernbjerg Formation (Fig. 3). The exposures along the coastal cliffs vary in quality. From a stratigraphic point of view they are generally good, whereas sedimentary structures commonly are obliterated by the effects of the Palaeogene sills and dykes.

For this study, five sedimentological sections were measured along the coast allowing construction of a W-E dip section (Fig. 3). The sections are correlated by lateral tracing of major sedimentary packages and drowning surfaces in the field and on a high-quality photo-mosaic, and by ammonite dating of a number of levels. The succession dips about $13^{\circ}$ to the east except in the easternmost section where it dips $9^{\circ}$ towards the north, but in this area dip-directions reflect disturbances by the immediately adjacent syenite complex (Fig. 1).
The oldest strata are exposed to the west immediately east of the Vælddal Fault where Jurassic strata rest directly on Triassic redbeds of the Fleming Fjord Formation (Stauber 1942). The base of the Middle Jurassic sandstones is not exposed further east, but fluvial to marginal marine sandstones and mudstones of the Bristol Elv Formation (Price \& Whitham 1997; Stemmerik et al. 1997; Therkelsen \& Surlyk 2004, this volume) occur below marine Upper Bajocian sandstones of the Pelion Formation in two sections. Three of the measured sections (Fig. 3, sections 1-3) reach up into black mudstones of the Upper Oxfordian - Kimmeridgian Bernbjerg Formation.

\section{Stratigraphic development}

The basal part of the Jurassic succession consists of channelised, trough cross-bedded pebbly sandstones interbedded with dark grey laminated shales occasionally with thin sandstone ripples. Crude fining-upwards trends can be recognised, and rootlet beds are common. Palaeocurrents are mainly towards the south-west (Fig. 3). The interbedded shales contain abundant leaves and scattered tree trunks. Both facies contain scattered trace fossils of marine affinity.

The sandstones are interpreted as having been deposited in coastal rivers and the shales were formed by drowning of the fluvial system either due to delta switching and abandonment or to base-level rise. The trace fossils suggest some marine influence and deposition of the shales probably took place under estuarine conditions or in interdistributary bays. A succession of fluvial deposits at the base of the Jurassic succession of Traill $\varnothing$ was recognised independently by

\section{Facing page:}

Fig. 3. NW-SE-oriented dip-parallel correlation panel of the Bjørnedal Block, based on five measured sections along the south coast of Traill $\varnothing$ (for location, see Fig. 1B). Note the eastwards, down-dip decrease in sandstone-mudstone ratio and increase in the thickness of mudstone packages. The key motif is a coarsening-upwards parasequence composed of offshore mudstones, overlain by offshore transition zone heteroliths followed by shoreface sandstones. The parasequences stack into parasequence sets, numbered PS1-8 from below. The succession belongs from below to the dominantly fluvial Bristol Elv Formation, the marine sandstone-dominated Pelion Formation, the mudstone-dominated Fossilbjerget Formation, the Olympen Formation of interbedded marine sandstones and mudstones, and the dark, deeper marine mudstone-dominated Bernbjerg Formation. P., Pelion. 


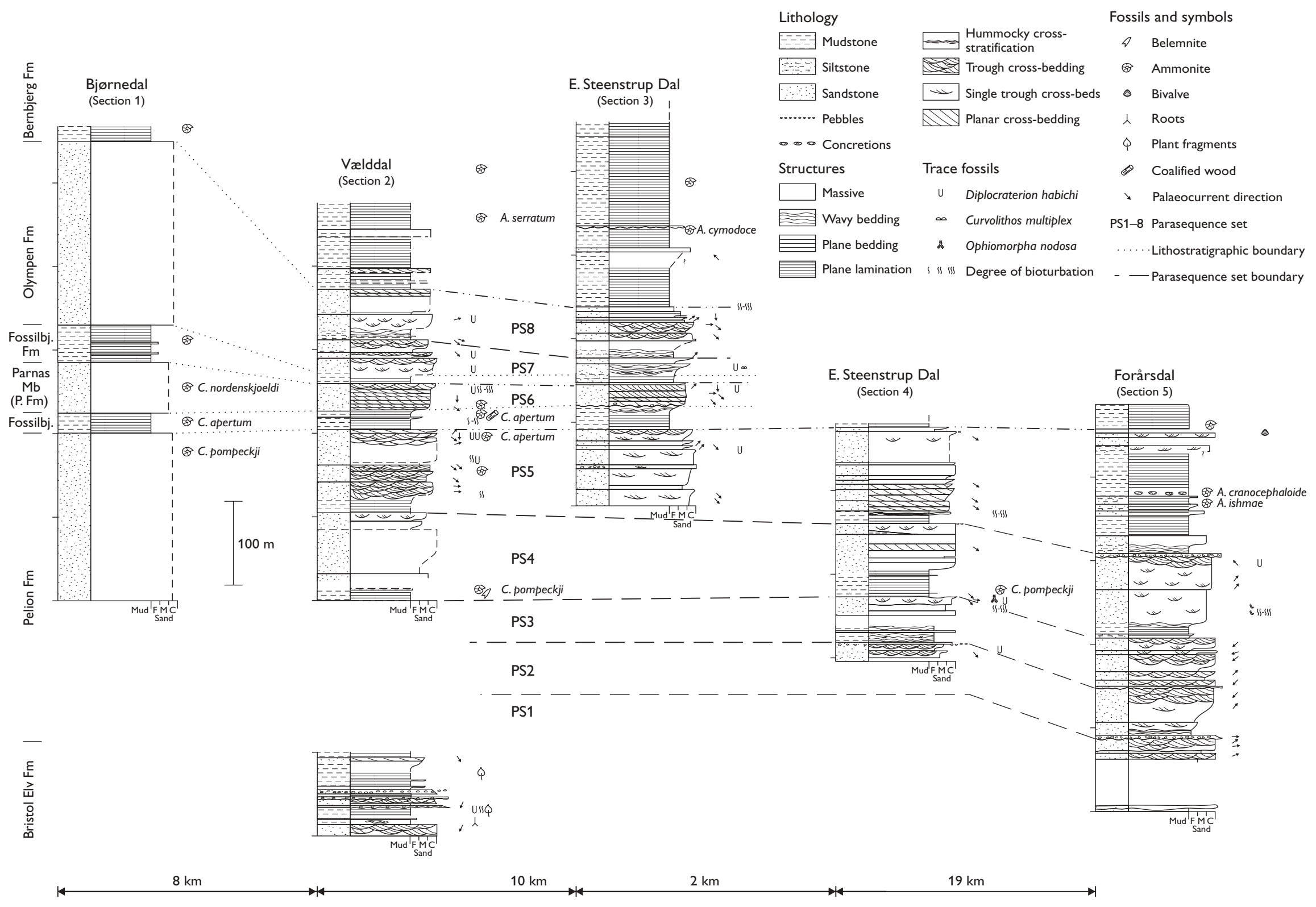




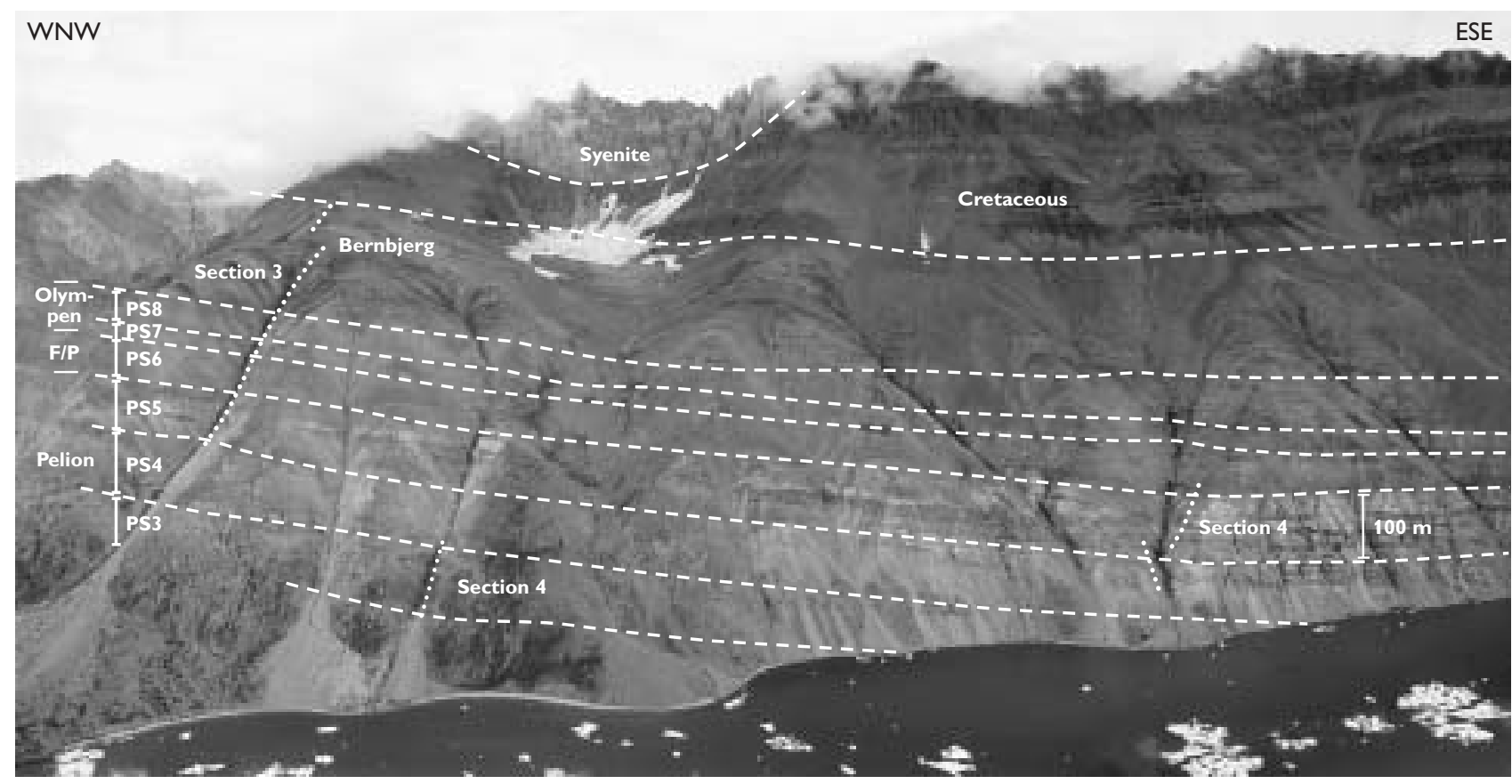

Fig. 4. The coastal section of the Bjørnedal Block, immediately east of Steenstrup Dal, showing yellow sandstones of the Pelion Formation below, overlain at a pronounced drowning surface by dark grey mudstones of the Fossilbjerget Formation followed by alternating sandstones and mudstones of the Olympen Formation, and finally by dark grey mudstones of the Bernbjerg Formation. The height of the cliff is approximately $1000 \mathrm{~m}$. PS3-8, parasequence sets; stippled lines, major flooding surfaces; F/P, Fossilbjerget and Pelion (Parnas Mb) Formations.

Price \& Whitham (1997) and Stemmerik et al. (1997) and is placed in the new Bristol Elv Formation by Therkelsen \& Surlyk (2004, this volume), who refer it tentatively to the Early Bajocian. The deposits described here from the south coast of Traill $\varnothing$ are also referred to the Bristol Elv Formation on the basis of the dominant pebbly sandstone lithology and the fluvial style of deposition. The boundary between the Bristol Elv Formation and the overlying marine sandstones of the Pelion Formation is not exposed.

The Bristol Elv Formation is overlain by marine sandstones and thin mudstones of the Pelion, Fossilbjerget and Olympen Formations, which are composed of coarsening-upwards units a few to several tens of metres thick. These units start with dark grey laminated to bioturbated offshore mudstones with thin subordinate beds of silty fine-grained sandstone or mediumgrained sandstone, overlain by heterolithic deposits, which give way to medium- to coarse-grained trough and planar cross-bedded sandstones. The boundary between the mudstones and the sandstones is usually gradational but is sharp and erosional in a few cases. The transitional interval shows hummocky cross-stratification in some sections. The top of the coarseningupwards units is a sharp drowning surface, overlain by offshore mudstones of the next unit, occasionally with an intervening pebble lag composed of subrounded to rounded quartzite pebbles up to $3 \mathrm{~cm}$ long. Metre-long U-burrows of Diplocraterion habichi extend downwards from the drowning surface.

The coarsening-upwards units were formed by progradation of shoreface sands across offshore transition zone heteroliths and offshore mudstones and are bounded by drowning surfaces. In some cases these surfaces have been modified by transgressive shoreface erosion and may conceal subtle sequence boundaries. The thickest and coarsest pebble lag, which occurs in the most distal section, suggests bypass of the beach during sea-level fall and subsequent transgressive shoreface winnowing and erosion. The units thus represent parasequences or simple sequences, but in this context they are for simplicity termed parasequences throughout. In some of the parasequences, the sandstone part has a sharp base formed by shoreface erosion during progradation under sea-level fall and interpreted as a forced regressive surface of erosion. The parasequences stack in parasequence sets, which are numbered PS1-8 (Fig. 3).

A total of six parasequence sets are recognised in the Pelion Formation. Parasequence set 6 is much finer 
grained than the lower parasequence sets and lithostratigraphically it represents interfingering between mudstones of the Fossilbjerget Formation and the Lower Callovian Parnas Member of the Pelion Formation (Alsen \& Surlyk 2004, this volume). The Pelion-Fossilbjerget parasequence sets thus constitute a composite aggradational to retrogradational package (Figs 3, 4).

Sandstones and mudstones of the Olympen Formation overlie the interfingering Pelion-Fossilbjerget couplet. This unit has not yielded any ammonites in the studied sections, but is elsewhere of Early-Middle Oxfordian age (Surlyk 1978; Price \& Whitham 1997) and this age assignment is corroborated by the bracketing Callovian age of the top of the Fossilbjerget Formation and Late Oxfordian base of the overlying Bernbjerg Formation. The Olympen Formation is composed of about five stacked coarsening-upwards units, which are thinner and finer grained than those of the Pelion Formation. They are interpreted as parasequences and form two parasequence sets, PS7-8, the lower of which includes the uppermost mudstones of the Fossilbjerget Formation (Fig. 3). This development is similar to the type area in central Jameson Land, where the formation also comprises two thick sandstone units and an intervening mudstone unit (Larsen \& Surlyk 2003). The Olympen Formation is overlain by black offshore mudstones with a few thin sandstones of the Upper Oxfordian - Kimmeridgian Bernbjerg Formation, reflecting final drowning of the sandy depositional systems.

The marine Middle and Upper Jurassic succession of south-east Traill $\varnothing$ thus shows a stepwise backstepping trend. It commences with the lower aggradational to retrogradational parasequence sets of the Pelion Formation dominated by rather coarse-grained sandstones topped by the intertonguing Fossilbjerget Formation mudstones and finer grained sandstones of the Parnas Member (Pelion Formation). Then follows the overall finer grained Olympen Formation, which is overlain by the Bernbjerg Formation mudstones. The main backstepping events can be roughly dated to the Callovian-Oxfordian and Middle-Late Oxfordian boundaries.

\section{Major drowning surfaces}

The drowning surfaces separating the thicker parasequence sets can be traced between the sections. It is difficult to evaluate their significance and regional extent but the drowning surfaces topping parasequence sets 3 and 5 are well dated palaeontologically and seem to represent regional flooding events (Figs 3, 4). Cranocephalites pompeckji thus characterises one such event, which can be traced from southern Jameson Land to Traill $\varnothing$ and possibly as far north as Hold with Hope (Vosgerau et al. 2004, this volume). The C. pompeckji Chronozone is Upper Bajocian, possibly reaching up into the lowermost Bathonian (Callomon 1993). Cadoceras apertum, which marks the base of the Callovian (i.e. $=$ C. apertum Chronozone of Callomon 1993, p. 103 ) is found $200 \mathrm{~m}$ above C. pompeckji. It seems likewise to represent a major regional flooding event (Piasecki \& Larsen 1998; Engkilde \& Surlyk 2003).

\section{Palaeocurrents}

Fluvial and marine palaeocurrents in the Middle Jurassic deposits of East Greenland are mainly axial towards the south with a subordinate northwards tidal component. The Bjørnedal Block represents a significant exception to this pattern. The fluvial Bristol Elv Formation shows palaeocurrents towards the south-west in the western part of the dip transect (Figs 3, 5). The palaeocurrents of the overlying marine sandstones of the Pelion and Olympen Formations are, however, mainly towards the south-east and north-east (Figs 3, 5), and marine currents thus essentially moved down the hangingwall slope in an offshore direction. A subordinate SW-NE-oriented tidal system is recorded in the easternmost section (Figs 3, 5).

\section{Down-dip facies development on the Bjørnedal Block}

A marked change in facies is recorded down the hangingwall of the Bjørnedal Block (Fig. 3). The up-dip western sections are more sand-rich, and mudstone units are relatively thin. Down-dip, the mudstone units become thicker and the whole succession expands in thickness. The interval from the Upper Bajocian Cadoceras pompeckji Chronozone to the Lower Callovian C. apertum Chronozone is thus about $200 \mathrm{~m}$ thick towards the west and increases to at least $250 \mathrm{~m}$ at the eastern down-dip end of the section. The thicknesses are measured between the correlative drowning surfaces, and the down-dip thickness increase thus amounts to $50 \mathrm{~m}$ over $20 \mathrm{~km}$. The western up-dip area is thus slightly condensed compared to the down-dip area, and was bypassed by much of the finer-grained 


\section{Bristol Elv Fm}

Vælddal and E. Steenstrup Dal

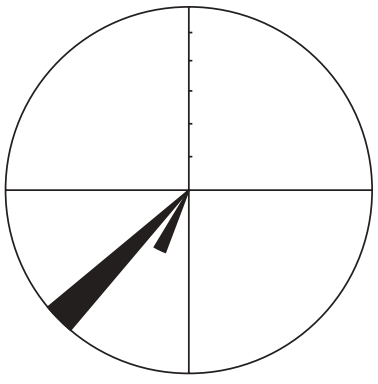

$N=5$

Circle $=60 \%$

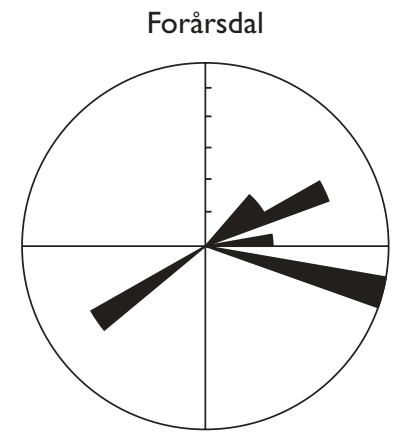

$N=10$

Circle $=30 \%$

\section{Pelion Fm}

Vælddal and E. Steenstrup Dal

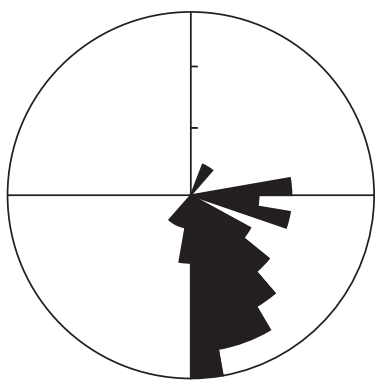

$N=40$

Circle $=15 \%$

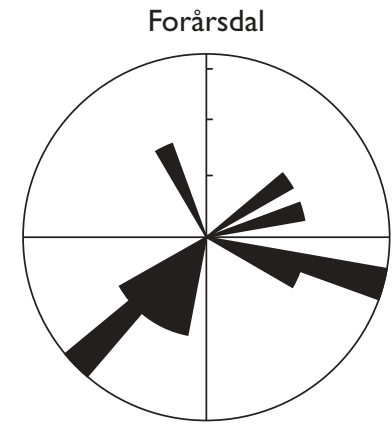

$N=12$

Circle $=15 \%$ sediment, which was deposited on the lower parts of the hangingwall slope where creation of accommodation space was greater.

\section{Comparison of stratigraphy on $\mathrm{W}$ - and E-dipping blocks}

The eastwards-dipping Bjørnedal Block contains thick mudstone units at the base of the parasequence sets. This contrasts markedly with the Pelion Formation parasequences on the wide westwards-dipping blocks elsewhere in East Greenland, which consist almost exclusively of sandstones (Engkilde \& Surlyk 2003). The marine palaeocurrents are mainly towards the south-east on the Bjørnedal Block, whereas they are towards the south or SSW on the westwards-dipping blocks. The succession similarly shales out towards the south-east on the Bjørnedal Block and towards the S-SSW on the latter blocks. The most important difference is that sediment influx to the Bjørnedal Block was derived from bypass and overspill of the adjacent block to the west, as also noted by Carr (1998), whereas sediment influx to the west-dipping blocks was directly from rivers at the heads of the structurally controlled embayments.

\section{Stratigraphic implications}

The marine Middle Jurassic deposits in adjacent parts of East Greenland, notably in Jameson Land are placed in the proximal sandy Pelion Formation and the distal mudstone-dominated Fossilbjerget Formation. There is little interfingering between the two formations except for the upper part where the uppermost tongue of the Pelion Formation (Parnas Member) is intercalated within the top Fossilbjerget Formation (Heinberg \& Birkelund 1984; Engkilde \& Surlyk 2003).

The stratigraphic development of the Bjørnedal Block differs in its regular alternation between mudstones and sandstones, which form a composite aggradational to retrogradational stack of parasequence sets culminating in the black mudstones of the Bernbjerg Formation. A pragmatic solution to this stratigraphic problem is to place the lower sandstone-dominated yellow sandstone package of parasequence sets $1-5$ in the Pelion Formation. The overlying dark grey mudstone (lower part of parasequence set 6) is placed in the Fossilbjerget Formation and the overlying sandstone of parasequence set 6 in the Parnas Member of 
the Pelion Formation. The mudstone-sandstone boundary in parasequence set 6 is characteristically sharp and is well suited as a lithostratigraphic boundary. The mudstone of the lower part of parasequence set 7 forms the top tongue of the Fossilbjerget Formation (Alsen \& Surlyk 2004, this volume). The Olympen Formation comprises the sandstone-dominated upper part of parasequence set 7 and parasequence set 8 (Fig. 3).

The ages of the three formations, as here defined, fit well with other areas in East Greenland. The base of the Pelion Formation is not exposed or has not yielded any fossils but is thought to belong to the Upper Bajocian Cadoceras borealis Chronozone, in agreement with evidence from nearby areas in central Traill $\varnothing$. Parasequence sets 4 and 5 from the upper part of the formation belong to the C.pompeckji and C. apertum Chronozones, and the top of the formation (Parnas Member) falls in the basal part of the C. nordenskjoeldi Chronozone (Fig. 3). The lower wedge of the Fossilbjerget Formation is only $25 \mathrm{~m}$ thick and belongs to the C. apertum Chronozone. The age of the top wedge of the Fossilbjerget Formation (base of parasequence set 7) is poorly constrained but is probably still Callovian. This development is similar to that found in nearby Bjørnedal (Alsen \& Surlyk 2004, this volume) and in central Jameson Land (Engkilde \& Surlyk 2003).

\section{Palaeogeographic implications}

The south-eastwards down-dip palaeocurrent directions and proximal to distal facies changes of the Jurassic succession on the Bjørnedal Block indicate that the sea was open and deepest towards the east (Fig. 6). This contrasts with the adjacent parts of the Middle Jurassic basin of East Greenland which are characterised by $\mathrm{N}-\mathrm{S}$-oriented marine embayments limited to the east by elongated peninsulas, islands or submarine shoals formed by uplifted crests of westwardstilted blocks. These embayments were open and deepest towards the south as shown by overall southwardsdirected palaeocurrents and decrease in grain size (Surlyk 1977b, 1978, 2003; Surlyk \& Clemmensen 1983).

\section{Conclusions}

The Bjørnedal Block was formed during rifting initiated in Late Bajocian time (Carr 1998). The block is bounded to the west by the west-dipping Vælddal Fault and is tilted towards the east in contrast to the Middle-

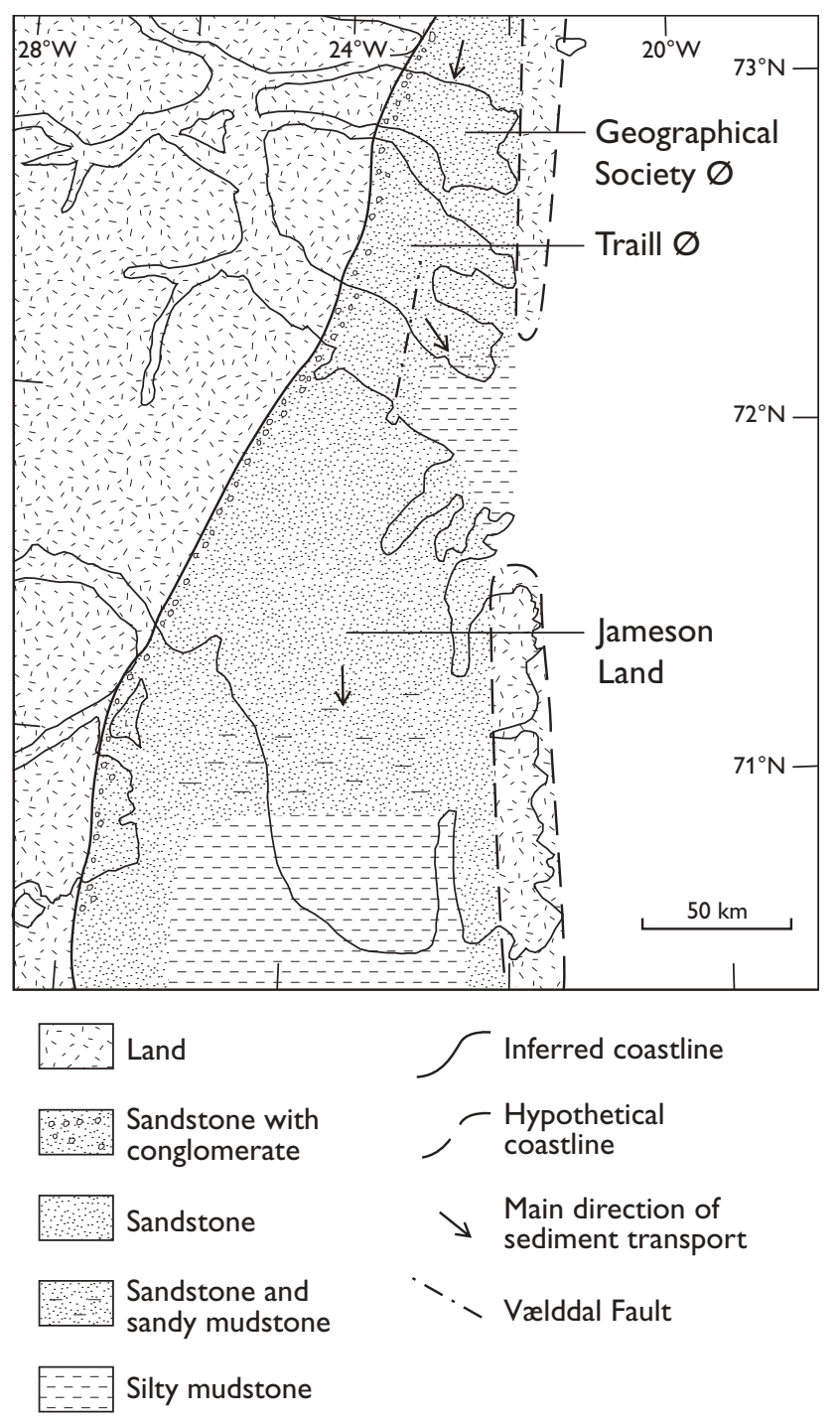

Fig. 6. Generalised Bathonian (Middle Jurassic) palaeogeography and facies distribution in the Geographical Society $\varnothing$, Traill $\varnothing$ and Jameson Land region. The sea was open towards east in the area comprising south-eastern Traill $\varnothing$ and north-eastern Jameson Land due to the east-dipping nature of the more than $30 \mathrm{~km}$ wide Bjørnedal Block, which was formed during early rifting. This contrasts with the remaining parts of the Jurassic basin of East Greenland where N-S-oriented marine embayments were limited to the east by elongated peninsulas, islands or submarine shoals formed by uplifted crests of westwards-tilted blocks. Based on Surlyk (1977b).

Late Jurassic west-dipping blocks characterising the rest of the Jurassic basin of East Greenland. The Middle lower Upper Jurassic succession in East Greenland shows mainly axial, southwards-directed palaeocurrents and sediment entered the basins at the head of faultcontrolled embayments. The succession on the Bjørnedal Block differs in showing east- and southeast-directed palaeocurrents and associated proximal 
to distal facies changes, transverse to the axis of the rift basin. The Middle Jurassic sediments bypassed the block west of the Vælddal Fault (Carr 1998) and spilled over onto the eastwards-dipping hangingwall of the Bjørnedal Block. Existing palaeogeographic reconstructions have thus been modified to account for the eastwards dip of the Bjørnedal Block. In this area the sea was open and deepened towards the east and there is no indication of a barrier or shoal to the east.

\section{Acknowledgements}

This paper is a contribution to the project 'Resources of the sedimentary basins of North Greenland and East Greenland' that is supported by the Danish Research Councils. We are grateful to Gregers Dam and Michael Larsen for constructive reviews.

\section{References}

Alsen, P. \& Surlyk, F. 2004: Maximum Middle Jurassic transgression in East Greenland: evidence from new ammonite finds, Bjørnedal, Traill Ø. In: Stemmerik, L. \& Stouge, S. (eds): The Jurassic of North-East Greenland. Geological Survey of Denmark and Greenland Bulletin 5, 31-49 (this volume).

Callomon, J.H. 1993: The ammonite succession in Middle Jurassic of East Greenland. Bulletin of the Geological Society of Denmark 40, 83-113.

Carr, I.D. 1998: Facies analysis and reservoir characterisation of Jurassic sandstones from Bjørnedal, central East Greenland, 245 pp. Unpublished Ph.D. thesis, Institute for Sedimentology, University of Reading, UK.

Donovan, D.T. 1953: The Jurassic and Cretaceous stratigraphy and palaeontology of Traill $\varnothing$, East Greenland. Meddelelser om Grønland 111(4), 150 pp.

Engkilde, M. \& Surlyk, F. 2003: Shallow marine syn-rift sedimentation: Middle Jurassic Pelion Formation, Jameson Land, East Greenland. In: Ineson, J.R. \& Surlyk, F. (eds): The Jurassic of Denmark and Greenland. Geological Survey of Denmark and Greenland Bulletin 1, 813-863.

Heinberg, C. \& Birkelund, T. 1984: Trace-fossil assemblages and basin evolution of the Vardekløft Formation (Middle Jurassic, central East Greenland). Journal of Paleontology 58(2), 362-397.

Koch, L. \& Haller, J. 1971: Geological map of East Greenland $72^{\circ}-76^{\circ} \mathrm{N}$. Lat. (1:250 000). Meddelelser om Grønland $\mathbf{1 8 3}$, 26 pp., 13 maps.
Larsen, M. \& Surlyk, F. 2003: Shelf-edge delta and slope deposition in the Upper Callovian - Middle Oxfordian Olympen Formation, East Greenland. In: Ineson, J.R. \& Surlyk, F. (eds): The Jurassic of Denmark and Greenland. Geological Survey of Denmark and Greenland Bulletin 1, 931-948.

Piasecki, S. \& Larsen, M. 1998: Biofacies and sequence stratigraphy in an intracratonic seaway, Middle to Upper Jurassic, East Greenland. Abstracts (CD-ROM), American Association of Petroleum Geologists 1998 annual meeting, Salt Lake City (Utah), 2 pp.

Price, S.P. \& Whitham, A.G. 1997: Exhumed hydrocarbon traps in East Greenland: analogs for the Lower-Middle Jurassic play of Northwest Europe. American Association of Petroleum Geologists Bulletin 81, 196-221.

Stauber, H. 1942: Die Triasablagerungen von Ostgrönland. Meddelelser om Grønland 132(1), 325 pp.

Stemmerik, L., Clausen, O.R., Korstgård, J., Larsen, M., Piasecki, S., Seidler, L., Surlyk, F. \& Therkelsen, J. 1997: Petroleum geological investigations in East Greenland: project 'Resources of the sedimentary basins of North and East Greenland'. Geology of Greenland Survey Bulletin 176, 29-38.

Surlyk, F. 1977a: Mesozoic faulting in East Greenland. In: Frost, R.T.C. \& Dikkers, A.J. (eds): Fault tectonics in N.W. Europe. Geologie en Mijnbouw 56, 311-327.

Surlyk, F. 1977b: Stratigraphy, tectonics and palaeogeography of the Jurassic sediments of the areas north of Kong Oscars Fjord, East Greenland. Bulletin Grønlands Geologiske Undersøgelse 123, 56 pp.

Surlyk, F. 1978: Jurassic basin evolution of East Greenland. Nature 274(5667), 130-133.

Surlyk, F. 2003: The Jurassic of East Greenland: a sedimentary record of thermal subsidence, onset and culmination of rifting. In: Ineson, J.R. \& Surlyk, F. (eds): The Jurassic of Denmark and Greenland. Geological Survey of Denmark and Greenland Bulletin 1, 659-722.

Surlyk, F. \& Clemmensen, L.B. 1983: Rift propagation and eustacy as controlling factors during Jurassic inshore and shelf sedimentation in northern East Greenland. Sedimentary Geology 34, 119-143.

Therkelsen, J. \& Surlyk, F. 2004: The fluviatile Bristol Elv Formation, a new Middle Jurassic lithostratigraphic unit from Traill $\varnothing$, North-East Greenland. In: Stemmerik, L. \& Stouge, S. (eds): The Jurassic of North-East Greenland. Geological Survey of Denmark and Greenland Bulletin 5, 19-29 (this volume).

Vosgerau, H., Larsen, M., Piasecki, S. \& Therkelsen, J. 2004: A new Middle-Upper Jurassic succession on Hold with Hope, North-East Greenland. In: Stemmerik, L. \& Stouge, S. (eds): The Jurassic of North-East Greenland. Geological Survey of Denmark and Greenland Bulletin 5, 51-71 (this volume). 